\title{
Peran Atribut Produk dalam Keputusan Pembelian Terkait Strategi Pemasaran Soyjoy di Area Bogor
}

\author{
The Role of Product Attributes on Consumer Buying Decision Related to Soyjoy \\ Marketing Strategy in Bogor Area \\ Rheinnadia $^{*}$, Abdul Kohar Irwanto ${ }^{2}$, dan Mukhamad Najib ${ }^{2}$ \\ ${ }^{1}$ Program Magister Manajemen Sekolah Pascasarjana IPB \\ ${ }^{2}$ Departemen Manajemen, Fakultas Ekonomi dan Manajemen, Institut Pertanian Bogor \\ Jl. Kamper, Kampus IPB Darmaga, Bogor 16680
}

\begin{abstract}
ABSTRAK
Di Indonesia persaingan bisnis makanan sangat beragam, karena industri yang menjanjikan ini hanya diisi oleh beberapa perusahaan besar dan kecil. Di antara berbagai macam produk yang dihasilkan perusahaan tersebut tidak banyak produk makanan yang menonjolkan sisi kesehatan sebagai produk konsumsi sehari-hari. Soyjoy merupakan produk healthy bar pertama di Indonesia. Penjualan di area Bogor menunjukkan pertumbuhan setiap tahunnya. Kondisi ini mendorong PT Amerta Indah Otsuka berinovasi dan melakukan pengembangan produk dengan berbagai atribut produk agar dapat menarik minat konsumen untuk melakukan pembelian. Tujuan yang ingin dicapai dari penelitian ini adalah mengidentifikasi karakteristik konsumen dan trend penjualan Soyjoy di area Bogor, menganalisis pengaruh mutu, citra merek, harga, dan kemasan terhadap minat beli di area Bogor, serta menganalisis atribut paling berpengaruh terhadap minat beli Soyjoy di area Bogor menggunakan metode SEM. Penelitian menunjukkan bahwa mutu, citra merek dan harga berpengaruh positif dan signifikan terhadap minat beli konsumen, dan minat beli konsumen berpengaruh positif dan signifikan terhadap keputusan pembelian, sehingga penelitian ini dapat memberikan jawaban atas masalah dalam penelitian ini yaitu mutu menjadi prioritas utama dalam menentukan pilihan diantara cemilan sehat yang beredar di pasar.
\end{abstract}

Kata kunci: keputusan pembelian, marketing mix, peran, atribut produk, strategi pemasaran,

\section{ABSTRACT}

Food business competition in Indonesia is very diverse, because this promising industry is populated only by several large and small companies. Among the wide range of products produced by the company, there are not many food products making health as daily consumption product. Soyjoy is the first healthy product bar in Indonesia. Soyjoy sales in the Bogor area actually showed growth each year. These conditions encourage PT Amerta Indah Otsuka as Soyjoy producer to innovate and develop products with different attributes of the product in order to attract consumers to make purchases. This research is aimed to describe the Soyjoy consumer characteristics and sales trends in the area of Bogor, the effect of quality, brand image, pricing, and packaging (jointly or partial) on Soyjoy consumer buying interest and which attributes is the most dominant influence on buying interest Soyjoy in Bogor area analyzed by Structural Equation Modeling (SEM). The study showed that the quality, brand image and price positive and significant impact on consumer buying interest, and consumer buying interest and a significant positive influence on purchasing decisions. This research may provide an answer to the problem that quality is the consumer top priority in determining the choice between healthy snacks in the market. To improve purchasing decisions, companies need to increase buying interest in advance through product quality, brand image and price.

Key words: buying decision, marketing mix, marketing strategy, role, product attributes

\footnotetext{
*) Korespondensi:

Jl. Kamper, Kampus IPB Darmaga, Bogor 16680; email: rheinnadia@gmail.com
} 


\section{PENDAHULUAN}

Industri makanan dan minuman di Indonesia dapat dikatakan mengalami partumbuhan cukup baik. Setiap tahunnya, ada banyak merek baru yang memasuki pasar. Gabungan Pengusaha Makanan dan Minuman (www.gapmmi.or.id) tahun 2014 memperkirakan nilai penjualan produk makanan dan minuman pada tahun 2014 tumbuh 6\% menjadi 797 Triliun Rupiah, relatif sama dengan pertumbuhan tahun sebelumnya.

Di Indonesia, persaingan bisnis makanan sangat beragam, industri yang menjanjikan ini diisi oleh beberapa perusahaan besar dan kecil. Berdasarkan data yang tercatat di Badan Pusat Statistik (BPS), jumlah perusahaan industri besar sedang makanan mencapai 5.852 perusahaan di tahun 2013. Di antara berbagai macam produk yang dihasilkan perusahaan tersebut tidak banyak produk makanan yang menonjolkan sisi kesehatan sebagai konsumsi sehari-hari. Soyjoy merupakan produk healthy bar pertama di Indonesia. Bahan dasar Soyjoy adalah kedelai yang mengandung protein tinggi, tidak seperti produk snack lain yang berbahan dasar terigu.

Pada tahun 2013, penjualan Soyjoy di Indonesia, mengalami peningkatan $27 \%$ setelah di tahun sebelumnya sempat mengalami penurunan $46 \%$. Sebaliknya penjualan di area Bogor justru menunjukkan pertumbuhan setiap tahunnya. Pada tahun 2013 penjualan di area Bogor meningkat sebesar $49 \%$ dengan rataan pertumbuhan per tahun $52 \%$. Data penjualan selengkapnya dapat dilihat pada Tabel 1.

Tabel 1. Data penjualan dan tingkat pertumbuhan Soyjoy di Indonesia dan area Bogor

\begin{tabular}{ccccc}
\hline Tahun & $\begin{array}{c}\text { Penjualan di } \\
\text { Indonesia } \\
\text { (Rupiah) }\end{array}$ & $\begin{array}{c}\text { Tingkat } \\
\text { Pertumbuhan } \\
(\%)\end{array}$ & $\begin{array}{c}\text { Penjualan di } \\
\text { area Bogor } \\
\text { (Rupiah) }\end{array}$ & $\begin{array}{c}\text { Tingkat } \\
\text { Pertumbuhan } \\
(\%)\end{array}$ \\
\hline 2009 & $15,561,803,726$ & & 103.654 .080 & \\
2010 & $21,077,705,189$ & 35 & 143.879 .564 & 39 \\
2011 & $18,358,750,367$ & -13 & 238.209 .054 & 66 \\
2012 & $9,863,635,868$ & -46 & 249.984 .409 & 5 \\
2013 & $12,524,934,074$ & 27 & 495.961 .609 & 98 \\
\hline
\end{tabular}

Sumber: Data Primer Diolah (2014)

Menurut Manajer Pemasaran PT Amerta Indah Otsuka, kenaikan penjualan di area Bogor ini dikarenakan selain melakukan promosi, Soyjoy juga memberikan edukasi kepada masyarakat mengenai manfaatnya. Selain itu adanya perubahan trend konsumsi masyarakat yang sudah semakin peduli dengan kesehatan menjadikan Soyjoy salah satu camilan sehat yang digemari.

Munculnya beberapa produk snack sehat sejenis di tahun 2011 seperti Oatbits dan Fitbar di tahun 2012 menyebabkan tingkat pertumbuhan penjualan Soyjoy di area Bogor turun 5\%. Hal ini menunjukkan bahwa persaingan di industri makanan ringan semakin ketat. Kondisi ini mendorong PT Amerta Indah Otsuka untuk berinovasi dan melakukan pengembangan produk dengan berbagai atribut produk untuk menarik minat konsumen agar melakukan pembelian. Unsur-unsur atribut produk menurut Kotler (2008) terdiri dari mutu, fitur dan dimensi produk. Menurut Simamora (2002:79) atribut produk adalah faktor-faktor yang dipertimbangkan konsumen dalam mengambil keputusan tentang pembelian suatu merek ataupun kategori produk, yang melekat pada produk atau menjadi bagian produk itu sendiri.

Merek merupakan atribut yang memberikan manfaat non materiil, yaitu kepuasan emosional, terdiri atas: mempertimbangkan merek sebelum membeli snack sehat, memilih merek healthy bar tertentu dan memilih healthy bar yang terkenal. Sejauh ini menurut hasil dari survey yang dilakukan oleh Top Brand Award 2013, merek Soyjoy menjadi top of mind (TOM) snack bar yang masih mendominasi pasar, hal ini dapat dilihat dari besarnya responden yang memilih Soyjoy $(49,8 \%)$. Harga merupakan pengorbanan riil dan materiil yang diberikan oleh konsumen untuk memperoleh atau memiliki produk, dengan mempertimbangkan peubah: membandingkan harga sebelum membeli snack sehat, memilih snack sehat yang harganya murah, memilih snack sehat yang harganya sebanding dengan mutunya, memilih snack sehat yang mendapat hadiah pembelian. Dengan membandingkan Soyjoy terhadap kategori produk sejenis, tentunya konsumen mempunyai alasan mengkonsumsi produk ini, karena di satu sisi harus membayar lebih mahal untuk membeli Soyjoy. Data perbandingan harga healthy bar di area Bogor dapat dilihat pada Tabel 2.

Tabel 2. Harga jual produk healthy bar di area Bogor (Rupiah) Tahun 2014

\begin{tabular}{lc}
\hline \multicolumn{1}{c}{ Merk } & Harga (Rupiah/bar) \\
\hline Soyjoy & 6.100 \\
Fitbar & 3.900 \\
Oatbits & 3.600 \\
\hline
\end{tabular}

Agar dapat mencapai kesuksesan di dunia bisnis, perusahaan harus konsisten dalam meningkatkan mutu produk maupun layanannya. Salah satu langkah yang akan diambil PT Amerta 
Indah Otsuka dalam upaya meningkatkan mutu Soyjoy adalah dengan mengimpor Soyjoy langsung dari Otsuka Pharmaceutical Jepang pada tahun 2015. Sebagai pelopor camilan sehat yang enak dikonsumsi, Soyjoy memiliki perbedaan kemasan dari produk lainnya yang sejenis. Desain kemasan yang praktis, mudah digenggam dan didukung dengan desain gambar modern mampu mendeskripsikan isi produk di dalamnya.

Berdasarkan latar belakang masalah yang telah diuraikan, terungkap manfaat kesehatan dan kelebihan lain yang ditawarkan Soyjoy sebagai snack sehat tidak serta merta diikuti dengan angka penjualan yang konsisten di Indonesia. Selain itu, rencana strategic (renstra) Soyjoy untuk mengimpor langsung dari Jepang selain dirasa mampu meningkatkan mutu juga berdampak pada penjualan Soyjoy ke depannya. Perlu diperhatikan bahwa varian rasa yang ditawarkan Soyjoy yang diimpor dari Jepang apakah akan mengubah rasa Soyjoy yang selama ini sudah dikenal konsumennya dan apakah sudah sesuai dengan selera konsumen di Indonesia, khususnya di area Bogor. Selain itu peningkatan mutu, biasanya diikuti dengan peningkatan harga secara langsung yang dapat memengaruhi perilaku konsumen dalam memutuskan pembelian suatu produk. Meskipun penjualan Soyjoy di area Bogor bertumbuh dengan konsisten dari tahun ke tahun, perubahan atribut produk Soyjoy harus tetap diwaspadai agar tidak memberikan pengaruh negatif pada penjualannya.

Tujuan penelitian ini adalah: (1) Mengidentifikasi karakteristik konsumen dan trend penjualan Soyjoy di area Bogor, (2) Mengetahui dan menganalisis pengaruh kualitas, citra merek, harga, dan kemasan terhadap minat beli di area Bogor, (3) Menganalisis atribut yang paling berpengaruh terhadap minat beli Soyjoy di area Bogor, (4) Menganalisis dampak dari minat beli konsumen terhadap keputusan pembelian Soyjoy di area Bogor, dan (5) Mengkaji implikasi perilaku konsumen Soyjoy terhadap bauran pemasaran berdasarkan studi yang telah dilakukan.

\section{METODE PENELITIAN}

Penelitian ini dilakukan di tempat-tempat yang menjual Soyjoy di area Bogor seperti pasar swalayan, rumah sakit, apotek dan toko kelontong. Pemilihan lokasi ini dilakukan secara sengaja (purposive), hal ini dikarenakan penulis ingin mengetahui respon dari konsumen Soyjoy di area Bogor. Data dikumpulkan menggunakan metode wawancara berdasarkan daftar pertanyaan kepada para konsumen.

\section{Metode Pengolahan dan Analisis Data}

1. Statistik Deskriptif

Statistik deskriptif digunakan untuk mengetahui karakteristik konsumen dan trend penjualan Soyjoy di area Bogor, disamping menyusun gambaran umum implikasi perilaku konsumen terhadap bauran pemasaran Soyjoy.

2. Teknik Statistika

Metode pengolahan data yang digunakan dalam penelitian ini adalah analisis Partial Least Square (PLS). PLS merupakan salah satu metode dari Struktural Equation Modelling (SEM) berbasis varian, yang digunakan untuk menyelesaikan permasalahan pada data seperti ukuran contoh kecil, adanya data hilang dan adanya multikolinieritas (Jogiyanto dan Abdillah, 2009).

\section{HASIL DAN PEMBAHASAN}

\section{Karakteristik Konsumen Soyjoy}

Dari 100 kuesioner yang mengikuti survey, karakteristik konsumen Soyjoy dapat dilihat pada Tabel 3.

Tabel 3. Karakteristik Konsumen Soyjoy di area Bogor

\begin{tabular}{clcclc}
\hline No & \multicolumn{1}{c}{ Keterangan } & Jumlah & No & \multicolumn{1}{c}{ Keterangan } & Jumlah \\
\hline l & Wilayah Domisili & $\%$ & 2 & Jenis Kelamin & $\%$ \\
& Bekasi & 6 & & Perempuan & 68 \\
& Bogor & 52 & & Laki-laki & 32 \\
& Depok & 10 & $\mathbf{3}$ & Usia & $\%$ \\
& Jakarta Barat & 6 & & 18-25 tahun & 60 \\
& Jakarta Selatan & 8 & & 26-35 tahun & 32 \\
& Jakarta Timur & 4 & & $36-45$ tahun & 8 \\
& Jakarta Utara & 4 & & \\
& Tangerang & 4 & & \\
& Tangerang Selatan & 6 & & \\
& & & & \\
\hline No & \multicolumn{2}{c}{ Keterangan } & Jumlah & & \\
\hline 4 & Tingkat Penghasilan & $\%$ & & \\
& Rp1.000.000-5.000.000 & 64 & & \\
& Rp5.000.000-10.000.000 & 12 & & \\
& $>$ Rp10.000.000 & 24 & &
\end{tabular}

Trend adalah gerakan berjangka panjang yang menunjukkan adanya kecenderungan menuju ke satu arah kenaikan dan penurunan secara keseluruhan. Dari data penjualan yang ada, berikut perhitungan trend penjualan Soyjoy dengan (Gambar 1) Metode Kuadrat Terkecil (Least Square Method).

Berdasarkan hasil penelitian, diketahui trend penjualan Soyjoy di Area Bogor setiap tahunnya menunjukkan peningkatan. Hal ini dapat menjadi acuan bagi perusahaan untuk mempertahankan pelanggan yang ada dan kesempatan untuk meraih pangsa pasar baru. 


\section{Trend Penjualan}

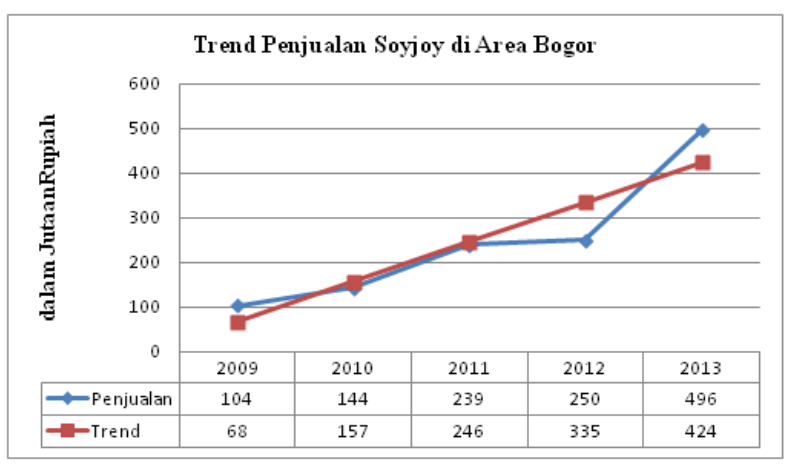

Gambar 1. Trend Penjualan Soyjoy

\section{Hasil Pengujian Hipotesis}

Pengujian hipotesis dapat dilakukan melalui pengukuran t-value, apabila t-value lebih besar dari 1,96 maka hipotesis diterima dan terdapat hubungan yang nyata antar. Nilai masing-masing t-value dapat dilihat pada Tabel 4 .

Tabel 4. Karakteristik Konsumen Soyjoy di Area Bogor

\begin{tabular}{ccccl}
\hline \multicolumn{1}{c}{ Path } & $\begin{array}{c}\text { Path } \\
\text { Coefficient }\end{array}$ & $\begin{array}{c}\text { Standard } \\
\text { Error }\end{array}$ & T-Value & Keterangan \\
\hline KL ? MB & 0.443 & 0.146 & 3.044 & Signifikan \\
CM ? MB & 0.299 & 0.138 & 2.165 & Signifikan \\
HP ? MB & -0.570 & 0.287 & 1.987 & Signifikan \\
KM ? MB & 0.569 & 0.303 & 1.877 & Tidak Signifikan \\
MB ? KP & 0.541 & 0.073 & 7.364 & Signifikan \\
\hline
\end{tabular}

Berdasarkan Tabel 4 dapat dianalisis hipotesis berikut:

\section{Pengaruh Mutu terhadap Minat Beli}

$\mathrm{H}_{01}$ : Mutu produk tidak berpengaruh terhadap minat beli konsumen Soyjoy

$\mathrm{H}_{\mathrm{a} 1}$ : Mutu produk berpengaruh terhadap minat beli konsumen Soyjoy.

Berdasarkan hasil analisis, besarnya pengaruh langsung peubah mutu produk terhadap minat beli konsumen Soyjoy adalah 0,449 dengan nilai t-value sebesar 3,044. Nilai $t$ value $\geq \pm 1.96$ maka hipotesis 0 ditolak, sehingga dapat dijelaskan terdapat pengaruh langsung dari mutu produk terhadap minat beli konsumen Soyjoy. Koefisien bernilai positif, sehingga dapat disimpulkan bahwa pengaruh mutu produk terhadap minat beli konsumen Soyjoy adalah positif, artinya semakin baik mutu produk maka Minat Beli konsumen Soyjoy akan meningkat. Begitu pula sebaliknya, semakin buruk mutu produk, maka minat beli konsumen Soyjoy akan menurun.

2. Pengaruh Citra Merek terhadap Minat Beli konsumen Soyjoy
$\mathrm{H}_{02}$ : Citra merek memiliki pengaruh terhadap minat beli konsumen dalam membeli Soyjoy

$\mathrm{Ha}_{\mathrm{a} 2}$ : Citra merek memiliki pengaruh terhadap minat beli konsumen dalam membeli Soyjoy

Berdasarkan hasil analisis, besarnya pengaruh langsung citra merek terhadap minat beli konsumen Soyjoy adalah 0,301 dengan $t$ value citra merek terhadap minat beli konsumen Soyjoy 2,165. Karena nilai $t$-value $\geq$ 土1.96, maka hipotesis nol ditolak, sehingga dapat dijelaskan terdapat pengaruh dari citra merek terhadap minat beli konsumen Soyjoy. Koefisien bernilai positif, sehingga disimpulkan pengaruh citra merek terhadap minat beli konsumen Soyjoy positif, artinya, semakin buruk citra merek, maka minat beli konsumen Soyjoy akan menurun.

3. Pengaruh Harga terhadap Minat Beli konsumen Soyjoy

$\mathrm{H}_{03}$ : Harga berpengaruh terhadap minat beli konsumen dalam membeli Soyjoy

$\mathrm{H}_{\mathrm{a} 3}$ : Harga berpengaruh terhadap minat beli konsumen dalam membeli Soyjoy

Berdasarkan hasil analisis, besarnya pengaruh langsung harga terhadap minat beli konsumen Soyjoy adalah -0,323 dengan t-value harga terhadap minat beli konsumen Soyjoy 2,165 . Karena nilai t-value $\geq \pm 1.96$, maka hipotesis nol ditolak, sehingga dapat dijelaskan bahwa terdapat pengaruh dari harga terhadap minat beli konsumen Soyjoy. Koefisien bernilai negatif, sehingga disimpulkan pengaruh harga terhadap minat beli konsumen Soyjoy adalah negatif. Artinya semakin tinggi harga, maka minat beli konsumen Soyjoy akan menurun, begitu pula sebaliknya, semakin rendah harga, maka minat beli konsumen Soyjoy akan meningkat.

4. Pengaruh Kemasan terhadap Minat Beli konsumen Soyjoy

$\mathrm{H}_{04}$ : Kemasan berpengaruh terhadap minat beli konsumen dalam membeli Soyjoy di Bogor $\mathrm{H}_{\mathrm{a} 4}$ : Kemasan berpengaruh terhadap minat beli konsumen dalam membeli Soyjoy di Bogor Berdasarkan hasil analisis, besarnya nilai t-value hubungan kemasan terhadap minat beli adalah 1,877 . Karena nilai $t$-value $< \pm 1.96$ maka hipotesis nol tidak ditolak, sehingga dapat dijelaskan bahwa tidak terdapat pengaruh langsung dari Kemasan terhadap Minat Beli konsumen dalam membeli produk Soyjoy. 


\section{Pengaruh Minat Beli terhadap Keputusan Pembelian Soyjoy}

$\mathrm{H}_{05}$ : Minat beli berpengaruh positif terhadap keputusan pembelian Soyjoy

$\mathrm{H}_{\mathrm{a} 5}$ : Minat beli berpengaruh positif terhadap keputusan pembelian Soyjoy

Berdasarkan hasil analisis, besarnya pengaruh langsung minat beli terhadap Keputusan Pembelian Soyjoy adalah 0.548 dengan nilai $t$-value 7,364 . Karena nilai $t$-value $\geq$ \pm 1.96 , maka hipotesis nol ditolak, sehingga dijelaskan terdapat pengaruh langsung dari minat beli terhadap Keputusan Pembelian Soyjoy.

Koefisien bernilai positif, sehingga disimpulkan pengaruh minat beli terhadap Keputusan Pembelian Soyjoy positif, artinya semakin tinggi Minat Beli maka Keputusan Pembelian akan meningkat. Begitu pula sebaliknya, semakin rendah minat beli, maka keputusan pembelian Soyjoy akan menurun.

\section{Implikasi Manajerial}

Menurut West, Wood dan Harger, Gaman dan Sherrington serta Jones dalam Margaretha dan Edwin (2012) ada 9 faktor yang memengaruhi food quality. Berdasarkan penelitian yang sudah dilakukan, beberapa faktor yang dirasa perlu diperbaiki oleh Soyjoy adalah:

1. Warna

Produk Soyjoy yang terbuat dari bahan kedelai alami dan buah-buahan yang dikeringkan membuat penampilan produk Soyjoy kurang menarik dan cenderung pucat, jika dibandingkan dengan produk pesaing lainnya seperti Fitbar atau Oatbits, sehingga disarankan produsen Soyjoy memperbaiki sedikit tampilan warna produknya agar lebih menarik dan menggugah selera konsumen.

2. Porsi

Rekomendasi konsumen melalui kolom dalam kuesioner adalah penambahan bobot Soyjoy dalam setiap kemasannya, karena porsi yang ada sekarang dirasa terlalu kecil dibandingkan dengan harga yang harus dibayar konsumen.

3. Rasa

Berdasarkan hasil penelitian, perbaikan mutu produk Soyjoy yang sebaiknya diutamakan oleh perusahaan adalah melakukan evaluasi varian rasa yang digemari konsumen dan melakukan penambahan variasi rasa. Penambahan variasi rasa ini merupakan faktor yang perlu dipertimbangkan, agar menarik minat konsumen yang tidak menyukai varian rasa yang ditawarkan saat ini. Selain itu, sesuai dengan rekomendasi konsumen di kolom yang disediakan dalam kuesioner, varian rasa yang ditawarkan masih perlu ditambah, karena masih ada varian rasa yang kurang cocok dengan penerimaan rasa lokal. Dengan adanya penambahan varian rasa, diharapkan dapat dijadikan alternatif pilihan rasa oleh konsumen Soyjoy.

4. Harga

Sejalan dengan rencana perusahaan yang akan mengimpor varian rasa dari Soyjoy, maka alternatif strategi penetapan harga yang dapat dilakukan oleh Soyjoy adalah melakukan penetration pricing yaitu keadaan dimana perusahaan berusaha memperkenalkan suatu produk baru dengan harga rendah, dengan harapan akan memperoleh volume penjualan yang besar dalam waktu relatif singkat.

\section{Promosi}

Alternatif strategi pemasaran yang dapat dilakukan perusahaan untuk mendukung iklan dan promosi yang sudah ada, adalah menjadi sponsor kegiatan-kegiatan tertentu yang ada di masyarakat. Disamping itu, berdasarkan saran responden, perusahaan perlu mempertimbangkan untuk memberikan diskon atau potongan harga untuk tingkat pembelian tertentu produk ini dan sewaktu-waktu dapat memberikan gratis untuk konsumen tertentu.

6. Tempat

Sistem distribusi merupakan suatu bagian penting dalam alur pemasaran suatu produk. Sistem distribusi yang baik dan dilakukan secara kontinu, akan menjadikan pasokan produk lancar dan selalu tersedia, sehingga produk sampai di tangan konsumen pada saat yang dibutuhkan. PT AIO menggunakan dua saluran distribusi menurut cara penyampaiannya, yaitu:

a. Saluran distribusi langsung

Menggunakan saluran distribusi langsung, yaitu melalui website www.toko-otsuka. com.

b. Saluran distribusi tidak langsung

Berdasarkan rekomendasi dari konsumen, alternatif strategi yang dapat dilakukan terkait dengan hal ini adalah perusahaan mulai mendistribusikan produk Soyjoy dan menjalin hubungan yang baik dengan para pedagang pengecer kecil, sehingga produk dapat dengan mudah ditemukan di sekitar lingkungan konsumennya. 


\section{KESIMPULAN}

1. Pada kategori karakteristik konsumen, secara umum responden penelitian berdomisili di Bogor, dan sisanya berasal dari luar Bogor seperti Bekasi, Depok dan Jakarta. Sebagian besar konsumen Soyjoy berjenis kelamin perempuan dan 32\% lainnya berjenis kelamin laki-laki. Usia rsponden yang paling dominan 18-25 tahun diikuti oleh kelompok usia 26-35 tahun. Sebagian besar responden (64\%) memiliki penghasilan Rp1.000.000-Rp5.000.000 per bulannya.

2. Dari penelitian diketahui mutu, citra merek dan harga memiliki pengaruh terhadap minat beli, sedangkan Kemasan tidak memiliki pengaruh langsung. Artinya semakin baik mutu, citra merek dan harga yang dimiliki Soyjoy, akan semakin tinggi pula minat beli masyarakat terhadap produk ini.

3. Pengujian hipotesis menemukan bahwa dari ketiga atribut tersebut, atribut mutu dengan loading factor tertinggi yaitu 3.044, memiliki pengaruh paling kuat terhadap minat beli dibandingkan dengan citra merek dan harga.

4. Citra merek dan harga berpengaruh positif dan nyata terhadap minat beli konsumen, dan minat beli konsumen berpengaruh positif dan nyata terhadap keputusan pembelian. Penelitian ini memberikan jawaban bahwa mutu menjadi prioritas utama dalam menentukan pilihan diantara cemilan sehat yang beredar di pasar.

5. Implikasi manajerial yang dapat dilakukan dalam perbaikan bauran pemasaran Soyjoy dari hasil penelitian ini adalah memperbaiki empat faktor yaitu produk, harga, promosi dan tempat.

\section{DAFTAR PUSTAKA}

Dimyati, M. 2012. Model Struktural Pengaruh Atribut Produk terhadap Kepuasan dan Loyalitas Pelanggan Produk Pond's. Jurnal. Universitas Jember.

Dinawan, M.R. 2010. Analisis Faktor-faktor yang Mempengaruhi Keputusan Pembelian (Studi Kasus pada konsumen Yamaha Mio PT Harpindo Jaya Semarang). Jurnal. Universitas Diponegoro.

Rahma, E.S. 2007. Analisis Pengaruh Mutu Layanan dan Citra Merek terhadap Minat Beli dan Dampaknya pada Keputusan Pembelian. Tesis. Universitas Diponegoro.
Arifiana, W.E., S. Kumadji, \& D. Fanani. 2012. Pengaruh Atribut Produk terhadap Keputusan Pembelian (Survei Pada Ibu Rumah Tangga Perumahan Bumi Asri Sengkaling RW 05 Desa Mulyoagung Kecamatan Dau Kabupaten Malang Pembeli Deterjen Rinso). Jurnal. Universitas Brawijaya.

Istiharini. 2006. Pengaruh Atribut Produk, Bauran Promosi, dan Harga Indomie dan Mie Sedaap terhadap Loyalitas Konsumen Indomie. Jurnal. Universitas Parahyangan.

Wijaya, B.H., H.D. Utami \& B.A. Nugroho. 2012. Pemasaran terhadap Keputusan Konsumen Membeli Produk Olahan Ayam di Rumah Makan Resto Gama Malang. Jurnal. Universitas Brawijaya.

Sumawan, U. 2011. Perilaku Konsumen Teori Dan Penerapannya. Bogor. Ghalia Indonesia.

Sekaran, U. 2011. Research Method for Business. Jakarta. Gramedia Pustaka Utama.

Rangkuti, F. 1999. Riset Pemasaran. Jakarta. Gramedia.

Haryono, S dan P. Wardoyo. 2012. Struktural Equation Modeling Dengan untuk Penelitian Manajemen menggunakan AMOS 18.00. Jakarta. Intermedia Personalia Utama.

Sumarwan, U. 2013. Riset Pemasaran dan Pelanggan. IPB PRESS: Indonesia. Edisi: 3.

Sumarwan, U. 2011. Perilaku Konsumen : Teori dan penerapan dalam Pemasaran. Ghalia Indonesia. Ed2.

Sugiyono. 2004. Metode Penelitian Bisnis. Bandung. Alfabeta, CV.

Suliyanto. 2005. Analisis Data dalam Aplikasi Pemasaran. Ghalia Indonesia. Bogor.

Kotler, P. \& G. Armstrong. 2008. Prinsip-Prinsip Pemasaran 1. Edisi keduabelas. Jakarta: Erlangga.

Kotler, P. \& K.L. Keller, 2008. Manajemen Pemasaran, Edisi 12. Jilid 1. Alih Bahasa Benyamin Molan. Penerbit PT Indeks: Jakarta. 2008. Manajemen Pemasaran, Edisi 12. Jilid 2. Alih Bahasa Benyamin Molan. Penerbit PT Indeks: Jakarta.

Simamora, B. 2002. Panduan Riset Perilaku Konsumen, Surabaya: Pustaka Utama.

Abdillah, W. dan H.M. Jogiyanto. 2009. Konsep Dan Aplikasi PLS (Partial Least Square) Untuk Penelitian Empiris. Badan Penerbit Fakultas Ekonomi dan Bisnis UGM, Yogyakarta. 